\title{
Natimortalidade suína em granjas industriais: distribuição, qualidade dos registros do parto e causas associadas à natimortalidade pré-parto, intraparto e pós-nascimento*
}

\author{
LUÍS GUSTAVO SCHNEIDER \\ Fernando Pandolfo Bortolozzo (Orientador - UFRGS) \\ Ivo Wentz (Co-Orientador - UFRGS)
}

Banca: David E.S.N. Barcellos (UFRGS), Ilmo Wentz (UFSM), Mari L. Bernardi (UFRGS), Paulo R. S. Silveira (Embrapa/CNPSA)

O objetivo do presente estudo foi analisar aspectos ligados à natimortalidade de leitões em granjas de suinocultura industrial. No total observaram-se 908 partos em 6 granjas. Em cada unidade os partos foram acompanhados em um período médio de 2 semanas, observados nas $24 \mathrm{~h}$ do dia. Todos os leitões paridos no período de observação foram identificados como fetos mumificados (MUM), natimortos (NAT), leitões nascidos vivos e totais. Os leitões NAT foram necropsiados e classificados como NAT pré-parto (PP), NAT intraparto (IP) e NAT pós-nascimento (PN). As variáveis coletadas nos partos observados foram: ordem de parto (OP); duração da gestação (DURG); escore corporal visual ao início do parto (ECV); duração do parto (DURAP); funcionário que atendeu o parto (FUNC); pressão de assistência ao parto (PAP); temperatura no interior da sala de parto ao início do parto (TEMP) e genética da fêmea (GEN). Em 4 granjas, ao final dos partos obtiveram-se os registros dos fetos MUM, leitões NAT e vivos segundo os funcionários (FUNCs) atendentes do parto para a posterior comparação com os resultados obtidos segundo a análise observacional. A análise estatística processouse através do estudo das diferenças observadas nos escores médios dos rankings, para as variáveis respostas PP, IP, PN e NAT segundo as diversas categorias das variáveis coletadas através do teste não-paramétrico de Wilcoxon, sendo as diferenças testadas pelo teste de Kruskal-Wallis. As médias das diferenças entre os registros quanto aos fetos MUM, leitões NAT, vivos e totais, efetuados pelos FUNCs e análise observacional durante o período de estudo, foram comparadas pelo teste " $\mathrm{t}$ " para amostras pareadas. Do total de fêmeas observadas ( $(n=908)$, aproximadamente $47 \%$ dessas pariram na ausência de NAT e apenas $24,1 \%$ das matrizes, as quais apresentaram 2 ou mais NAT ao parto, foram responsáveis por $69,5 \%$ da natimortalidade. Quanto ao momento da morte dos leitões NAT nas 6 granjas estudadas, a natimortalidade PP variou de 9,1 a 39,1\%, a IP de 51,2 a $77,3 \%$ e a PN de 8,1 a $19,4 \%$. As variáveis que influenciaram a natimortalidade (PP, IP, PN e NAT) foram a OP, o tamanho da leitegada (TL) e o FUNC atendente do parto. As fêmeas de OP $\geq 5$ apresentaram uma maior ocorrência de NAT que nas demais categorias de OP. A OP influenciou a natimortalidade IP, PN e NAT $(\mathrm{P}<0,05)$. Da mesma forma, leitegadas com mais de 12 leitões nascidos totais apresentaram uma maior natimortalidade que leitegadas com menos de 12 leitões. O TL foi capaz de influenciar a natimortalidade PP, IP, PN e NAT $(\mathrm{P}<0,05)$. O FUNC atendente do parto influenciou a natimortalidade IP e PN $(\mathrm{P}<0,05)$. Quanto aos erros de registros, observou-se que os fetos MUM e leitões nascidos totais foram os que apresentaram maiores falhas de anotações, sendo as diferenças significativas em todas as granjas estudadas $(\mathrm{P}<0,05)$.

Descritores: natimortalidade de leitões, natimortos, partos, momento da morte, pré-parto, intraparto, pós-nascimento, ordem de parto, tamanho da leitegada, funcionário, erros de registro.

Apresentada: 28 fevereiro 2002

\footnotetext{
* Dissertação de Mestrado no. 321 (Especialidade: Fisiopatologia da Reprodução). 96f. Programa de Pós-Graduação em Ciências Veterinárias, Faculdade de Veterinária de Porto Alegre - UFRGS. CORRESPONDÊNCIA: L.G. Schneider [e-mail: ppgcv@ vortex.ufrgs.br].
} 


\title{
Stillbirth in industrial swine farms: distribution, quality of farrowing's records and causes associated with prepartum, intrapartum and postpartum stillbirth ${ }^{* *}$
}

\author{
LUÍS GUSTAVO SCHNEIDER \\ Fernando Pandolfo Bortolozzo (Adviser - UFRGS) \\ Ivo Wentz (Co-Adviser - UFRGS)
}

Committee: David E.S.N. Barcellos (UFRGS), Ilmo Wentz (UFSM), Mari L. Bernardi (UFRGS), Paulo R. S. Silveira (Embrapa/CNPSA)

The present study was carried out to analyze aspects of stillbirth in industrial pig farms. 908 farrowings were observed in 6 farms. In each unit, farrowing was observed daily for 24 hours for 2 weeks. Piglets were recorded in the following classes for the observation period: mummified fetuses (MUM), stillborn (STL), liveborn and total born. The STL piglets were necropsied to assess the time of death, classifying in prepartum stillbirths (PP), intrapartum stillbirths (IP) and postpartum stillbirths (PN). The following variables were recorded: female parity; duration of gestation; corporal score at farrowing; farrowing lenght; labour quality; number of farrowings assisted simultaneously; temperature inside the farrowing house at parturition and genetics. In 4 farms, some control indexes were obtained directly from stockpeople for comparison with the results of our study (MUM fetuses records and STL piglets and live-born piglets). The statistical analysis was performed through the differences observed in score averages, for the variables PP, IP, PN and STL (total stillborn) according to variables classified in several categories through the non-parametric test of Wilcoxon, and the differences tested through the Kruskal-Wallis' test. The averages of differences between records regarding the MUM fetuses, STL piglets, live-born and total-born, collected by stockpeople and observational analysis during the study period were compared by $t$ test using paired samples. From the total number of observed females $(\mathrm{n}=$ 908), about $47 \%$ gave birth in STL's absence and only $24.1 \%$, with 2 or more STL at farrowing, were responsible for $69.5 \%$ of stillbirths. Regarding the moment of death of STL piglets in all 6 farms, the PP stillbirth varied from 9.1 to $39.1 \%$, IP from 51.2 to $77.3 \%$ and PN from 8.1 to $19.4 \%$. The variables that influenced stillbirth (PP, IP, PN and STL) were female parity, litter size and stockperson. Females with parity higher than 5 had STL occurence higher than others parity classes. Parity influenced IP, PN and STL $(\mathrm{P}<0.05)$. In the same way, litters with more than 12 total born piglets had stillbirth rate higher than litters with less than 12 piglets. The litter size influenced PP, IP, PN and STL ( $\mathrm{P}<0.05)$. The labour quality influenced IP and PN $(\mathrm{P}<0.05)$. Regarding mistakes in record taking, we observed that MUM and total number of piglets represented the most relevant flaws, with statistically significant difference in all studied farms $(\mathrm{P}<0.05)$.

Key words: stillbirth in pigs, stillborn piglets, farrowing, moment of death, prepartum, intrapartum, postpartum, parity, litter size, labour quality.

Presented: 28 february 2002 ** Master's Thesis no. 321 (Field: Theriogenology). 96p. Postgraduate Program in Veterinary Sciences, Faculdade de Veterinária de Porto
Alegre, Universidade Federal do Rio Grande do Sul (UFRGS) - Brazil. CORRESPONDENCE: L.G. Schneider [e-mail: ppgcv@ vortex.ufrgs.br]. 